\title{
Analysis of the Cooperation Model and Problem of College and Enterprise
}

\author{
Na Zhang ${ }^{1, a}$ \\ ${ }^{1}$ Liaoning Jianzhu Vocational College, Liaoyang, Liaoning 111000 \\ ${ }^{\mathrm{a}}$ email
}

Keywords: Cooperation Model, College and Enterprise, College Education

\begin{abstract}
This paper first analyzes the mode of cooperation between schools and enterprises, in the end what kind of cooperation model is interested in enterprises, different industries of different modes of cooperation between the choice of whether there are differences, which are worthy of study. At present, the mode of cooperation between schools and enterprises can be summed up in several categories: scientific research cooperation, establishment of practice base or continuing education base, enterprise organization of student activities, and some enterprises will employ university teachers to act as business consultants, involved in some public welfare activities involving colleges and universities. In so many modes of cooperation, regardless of what kind of business industry, are more likely to practice base this model, manufacturing and high-tech services will be more concerned about the scientific research aspects of a variety of cooperation models, such as: commissioned scientific research, cooperation Scientific research, colleges and universities for independent research projects to provide data, equipment or funds.
\end{abstract}

\section{Introduction}

Colleges and enterprises and the special role of each other caused by the community more and more attention, school-enterprise cooperation has become a hot topic of domestic and foreign experts and scholars. In China, the issue of production and research is hot, the role of government in the development of colleges and universities is unquestionable, and also play a guiding and mediating role in promoting cooperation between enterprises and universities, especially for China's current situation, the government in the school-enterprise cooperation Plays a pivotal role. Foreign experience tells us that with the continuous maturity of the cooperation mechanism, the government in the process of school-enterprise cooperation can gradually reduce the intervention mechanism, so that school-enterprise cooperation can also save more social resources. So, the study of enterprises and universities alone, the two subjects is even more practical significance. The university's main role is to educate and research, the community more and more emphasis on the scientific research achievements into the enterprise needs of the real productive forces; colleges and universities is the backbone of the entire social research, colleges and universities made a significant contribution to the enterprise, not just For enterprises to send a batch of another batch of talent, but also for the long-term development of enterprises to provide innovative thinking and technology. Enterprises as an important place to test the reform and teaching results of colleges and universities, not only for college students to provide employment opportunities, but also for the university's scientific research and development to provide funds, data and scientific research sites, the role of enterprises in colleges and universities is irreplaceable.

\section{The Mode of Cooperation between School and Enterprise in China}

Business and university cooperation model is varied, in addition to cooperation in scientific research and development, to provide internship positions, but also can be other ways, such as cooperative education, student activities and so on. Universities and enterprises should break through the shackles of traditional thinking, looking for the two sides are interested in the richer cooperation model. In the process of cooperation, colleges and universities can provide enterprises with outstanding talents, scientific process and advanced ideas, enterprises in cultivating students' 
comprehensive quality has a unique, school irreplaceable role.

Different enterprises on the different modes of cooperation to accept or not there is a difference. It shows the attitude of the firm to various modes of cooperation. In many modes of cooperation, most companies are more willing to choose to provide internship for college students. Enterprises to recruit interns is mainly to explore the future of the staff, talent is the decisive factor in the development of enterprises, enterprises in order to develop and grow need to continue to absorb high-quality talent and business to grow together; there is a major reason is to provide internship this Cooperative mode is simple, low cost, it is easy in the student internship process to tap the talent for the enterprise. Some other cooperation model has also been the concern of the enterprise: in the survey of 111 enterprises, 30\% of enterprises are willing to hire qualified teachers as a business consultant; $29 \%$ of enterprises will be commissioned by the University of enterprises to replace the product design or process improvement ; $27 \%$ of the enterprises will organize staff and university researchers to carry out technical research, commissioned by the university orientation training enterprise employees; $20 \%$ of enterprises will choose to provide equipment for students activities, funds; $16 \%$ of enterprises are willing to free funding for scientific research to obtain good Social reputation; $15 \%$ of the enterprises can provide scientific research data or places for colleges and universities. China's patent development and foreign countries there is still a big gap in the cooperation between universities and enterprises can also highlight this gap. Similar to Sweden and Germany, such as developed countries, enterprises through intermediaries or other means and universities for technology or patent transfer, which is one of the main ways to obtain technology; but in China, enterprises and universities in the patent communication is still insufficient.

In addition to the several main modes of cooperation described above, there are other modes of cooperation. For example, some large enterprises have set up special funds to help poor poor college students, which is a form of corporate social responsibility, the enterprise to establish a good social image has a positive effect. At present, many cooperation modes, the main cooperation between universities and enterprises is in scientific research, such colleges and universities are mainly science and engineering schools, the effect is more significant; there is a major cooperation is the school organization students into business practice, understanding of production technology and Business operations; hire business teachers as business consultants are also favored by many companies.

There are two main types of university research: horizontal research and vertical research. Horizontal scientific research is the enterprise, institutions and colleges and universities signed a research contract, commissioned by the University of scientific research personnel to provide technical advisory services, transfer the final scientific research, technical cooperation research and development projects. This kind of research project research cycle is short, applicability is strong. Longitudinal research refers to the relevant departments of the relevant departments to support the University of scientific research categories. Enterprises as an investment unit, the principle of cost-benefit allows enterprises to track the progress of scientific research anytime, anywhere, according to the progress of funding, timely detection of problems and solve the problem, to avoid causing significant economic losses, from this perspective, the economic benefits of horizontal Longitudinal scientific research of high economic efficiency. University research funding mainly comes from the government and enterprises and institutions, according to the type of scientific research can be scientific research funding model is divided into long-term research funding and horizontal research funding. Colleges and universities and enterprises and institutions directly to the production or development of enterprises to provide technical support for the funding received by the horizontal funding for research funding.

\section{Corporate willingness to cooperate and factors that affect the willingness to cooperate}

Cooperation between enterprises and enterprises interested in cooperation is different, because some companies only because of the school-enterprise cooperation is strange and interested in cooperation, but may not really want to cooperate with the university. Cooperation between enterprises and universities is divided into two categories according to their willingness to 
cooperate: that there is willingness to cooperate and no willingness to cooperate. In the course of the investigation, the author detailed to the enterprise interviewee one by one to explain the questionnaire involved in the various issues of the desired information, so the data information is accurate and reliable. Among the 111 enterprises surveyed, for some reasons, some companies expressed no willingness to cooperate, but these enterprises recognize that school-enterprise cooperation will contribute to the enterprise; there are enterprises on the school-enterprise cooperation showed a strong Interest, some of which are already have school-enterprise cooperation experience of the enterprise, and some companies have not yet worked with the university, but look forward to specific and feasible mode of cooperation. School-enterprise cooperation can bring great benefits to the enterprise, but why some companies still do not want to cooperate, in the end which factors will affect the company's willingness to cooperate, the focus of this research is to explore and analyze these factors.

With the gradual deepening of school-enterprise cooperation, colleges and universities have also realized more deeply the great role of enterprises in the development and expansion of colleges and universities. However, the present situation restrains the positive attitude of colleges and universities to seek the possibility of cooperation, because most of China's universities rely on government finance to develop, are non-profit institutions, in the process of school-enterprise cooperation, colleges and universities in a passive position, generally Is the enterprise has specific cooperation needs and then discuss cooperation with the university. It is important to improve the enthusiasm of colleges and universities, but it is more practical to study the factors that affect the willingness of cooperation. It can promote the cooperation between schools and enterprises more effectively. At present, there is a huge leap in school-enterprise cooperation. In order to dig out more cooperation possibilities, we need to find out the factors that can affect the willingness of the enterprises to cooperate. To find these factors, we can improve the enthusiasm of the enterprises. The first choice is to collect and collate the previous literature, and then invite some senior managers in the enterprise to comment on the rationality of these factors, and finally summed up. The factors that affect the cooperation between the enterprise and the university mainly refer to the objective environmental factors, namely the enterprise's own factors and the surrounding environmental factors. Including internal factors and external factors. This classification is classified according to the commonality of various factors, such as the internal factors of the enterprise can be changed through their own efforts, external factors will not be a single enterprise will transfer. These factors are not made out of thin air, but according to the final feedback of the information obtained by the enterprise, with objectivity.

The main business of the enterprise is divided into four categories, namely, traditional manufacturing, traditional services, high-tech manufacturing and high-tech services. Traditional manufacturing, including agricultural and sideline food processing industry, textile industry, wood processing and wood, bamboo, rattan, brown, grass products industry, ferrous metal smelting and rolling processing industry, non-ferrous metal smelting and rolling processing industry, metal products industry, handicrafts and Other manufacturing. Traditional services include transportation, warehousing, postal services, wholesale and retail, accommodation and catering, finance, real estate, leasing and business services, water conservancy, environmental and public facilities management, resident services and other services, education, health, social security and social welfare , Culture, sports and entertainment. High-tech manufacturing, including machinery, electronics manufacturing, including machine tools, special equipment, transportation tools, machinery and equipment, electronic communications equipment, equipment and so on. High-tech services include telecommunications and other information transmission services, scientific research, technical services and geological exploration, computer services and software.

The economic development level of the enterprises in the region is divided into three categories: the more developed regions, the middle areas and the more backward regions in 31 provinces, autonomous regions and municipalities in mainland China in recent years. China, which is the most economically developed areas including Shanghai, Beijing, Guangdong, Jiangsu, Zhejiang, Tianjin, Shandong, and middle areas including Liaoning, Chongqing, Shaanxi, Hubei, Hunan, Fujian, 
Heilongjiang, Anhui, Sichuan, Shanxi, Henan, Jilin, Hebei, Guangxi , Including the provinces, including Guizhou, Yunnan, Xinjiang, Gansu, Hainan, Qinghai, Ningxia, Tibet; the number of colleges and universities in the region: According to the 2009 education website published by the list of colleges and universities to obtain statistics on the provinces (municipalities, Autonomous regions) owned by the number of colleges and universities; where the level of comprehensive scientific and technological progress: the Ministry of Science and Technology announced the latest "2009 National Comprehensive Scientific and Technological Progress Monitoring Report" in the comprehensive technical and technical level index as a research indicator.

The relevant provisions of the Law of the People's Republic of China on Promoting the Transformation of Scientific and Technological Achievements and the Company Law provide a wide range of legal basis for school-enterprise cooperation. Many provinces have also introduced relevant policies and regulations to create and build a good environment for school-enterprise cooperation and platform to explore new mechanisms of cooperation, new models, for example, the Office of Science and Technology of Guangdong Province in 2007 promulgated the "Guangdong Province Ministry of Education, Base to identify and management approach (Trial) "to promote the local real estate research and cooperation to diversify the development.

\section{Conclusion}

Colleges and enterprises as the current development of social and economic development of the two main, how to unite them to play a greater role, has become the needs of the times, but also China's economic development needs of the big step. University of human resources, equipment, high-tech enterprise development is necessary, enterprises are colleges and universities to achieve the value of these sites, enterprises and universities in the development of each other on the road is irreplaceable, to strengthen cooperation between them can achieve the efficient social resources Configuration, we have reason to believe that through the joint efforts of enterprises and universities, school-enterprise cooperation will come out of a more broad road.

\section{References}

[1] Li Junjun. Analysis of the cooperation between enterprises and universities [J]. Science and Technology Information Development and Economy. 2010 (29)

[2] $\mathrm{Xu}$ Shiwei, Li Ting.Technology innovation and practice of practice teaching under the background of school - enterprise cooperation [J].Education and Teaching Research. 2010 (07)

[3] Song Andong. School-enterprise interaction to cultivate innovative talents model - Taking Henan Agricultural University as an example [J]. China Science and Technology Information. 2010 (03)

[4] Chen Wenbin.School-enterprise cooperation is the only way to the development of university education [J]. Technology Information. 2009 (31)

[5] Zhang Guoping, Wang Yanchun. The current university and enterprises to cultivate talents in the plight and the way out [J].Journal of East China Institute of Technology (Social Science Edition). 2009 (03)

[6] Xiong Yi new. On the new economic situation to strengthen school-enterprise cooperation thinking [J]. Old area construction. 2009 (14) 